УДК 687.016: 687.03: 677.074

DOI: $10.30857 / 2617-$ 0272.2018 .1 .10
МИХАЙЛЮК О.Ю., КОЛОСНІЧЕНКО М.В., ОСТАПЕНКО Н.В., ГАЙОВА І.Л., АНТОНЮЖЕНКО А.Ю.

olga.knutd@meta.ua

mv.kolosnichenko@gmail.com

cesel@ukr.net

khmk@ knutd.com.ua

kepo@knutd.com.ua

Київський національний університет технологій та дизайну

\section{УЗАГАЛЬНЕНА СИСТЕМАТИЗАЦІЯ РІЗНОВИДІВ ФАКТУР МАТЕРІАЛІВ ДЛЯ ДИЗАЙН-ПРОЕКТУВАННЯ ОДЯГУ}

Мета. Метою дослідження є розробка узагальненої класифікації різновидів фактур матеріалів для виготовлення одягу та інших виробів.

Методологія. Використано комплекс загальнонаукових підходів: візуально-аналітичний, системно-інформаиійний та метод класифікацій.

Результати. На основі проведених досліджень проаналізовано та узагальнено існуючі різновиди фактур матеріалів для виготовлення одягу та інших виробів. Виокремлено і розкрито особливості формування та прогнозування сприйняття тектонічно досконалого одягу.

Наукова новизна. На основі теоретичних досліджень класифіковано існуючі різновиди фактур матеріалів для виготовлення одягу та інших виробів за різними критеріями, систематизовано способи їх виробництва. Доведено можливість прогнозування сприйняття гармонійного художньо-виразного образу завдяки застосуванню фактурних ефектів.

Практична значимість. Сформовано інформачійну базу різновидів фактур матеріалів для дизайн-проектування одягу та інших виробів.

Ключові слова: дизайн-проектування, фактура, класифікаиія, одяг.

Вступ. Розробка нових матеріалів для дизайн-проектування одягу та текстильних виробів $\epsilon$ одним 3 найважливіших етапів сучасної фешн-індустрії. Використовуючи матеріал як джерело творчості, дизайнер бере до уваги його пластичність, драпірувальність, здатність до формоутворення та фактуру, які залежать від сировинного складу, способу виготовлення, обробки, оздоблення тощо. Відповідно до задуму автора та ескізу виробу обираються методи проектування і матеріали 3 набором властивостей, за допомогою яких можна отримати бажану форму.

Постановка завдання. Структура поверхні тканини, шкіри, хутра та їх комбінування $\epsilon$ одним 3 основних носіїв візуальної і тактильної інформації про виріб. Недостатня увага до властивостей фактури, невдале поєднання різних матеріалів в одному виробі часто призводить до роздробленості і дисгармонії форми, i, як наслідок, несприйняття образу. Фактура, як один 3 інструментів дизайну одягу та інших виробів, потребує оптимального застосування, а значить більш детального вивчення і систематизації іï різновидів за різноманітними класифікаційними
Загальнотеоретичні дослідження фактур матеріалів присвячені вивченню їх окремих характеристик, розпорошених у різних джерелах, але з позицій системного підходу досліджень за цією тематикою не проводилося.

Результати досліджень. Композиційна побудова та конструктивно-технологічне рішення проектованого виробу багато в чому залежить і від фактури матеріалу. Зазвичай вибір затребуваних матеріалів для відтворення ідеї грунтується на основі власного досвіду дизайнера за візуальними $\mathrm{i}$ тактильними відчуттями. Часто для проектування одягу та інших виробів спочатку обирають матеріали, які потім стають творчою ідеєю і надають креативний імпульс для розробки ескізів та створення гармонійного образу. Системний підхід до вивчення структури поверхні тканини, трикотажу, хутра, шкіри, нетканого полотна та інших матеріалів значно полегшує процес обгрунтованого вибору матеріалів та оптимальних проектних рішень при дизайнпроектуванні одягу та інших виробів.

Відомо, що важливу роль у створенні пластичної форми одягу та інших виробів відіграє характер структури поверхні, тобто фактура матеріалу (від лат. factura - обробка, 
будова), його лицьова поверхня, одержана в результаті певної технологічної обробки [1].

Сьогодні фактура матеріалу є одним 3 важливих інструментів дизайну одягу та текстильних виробів і потребує ретельного дослідження. Сучасне виробництво пропонує широкий вибір тканин, нетканих матеріалів, трикотажних полотен, штучної та натуральної шкіри і хутра тощо від оптимального вибору яких залежить тектоніка зовнішнього вигляду та функціональність виробу.

Структура поверхні матеріалу може виконувати декоративну роль або обмежуватись лише функціональним призначенням. Фактура як активна властивість поверхні сприяє сприйняттю виробу легким або важким, об'ємним чи пласким, щільним, прозорим тощо. Для активізації фактурних ефектів використовують поєднання різних матеріалів у нетрадиційних комбінаціях, оригінальну обробку та оздоблення декоративними елементами [2].

Такі прийоми дозволяють створювати яскраві самодостатні фактури, які можуть існувати як окремі вироби.

На основі проведених досліджень проаналізовано, систематизовано та класифіковано існуючі різновиди фактур матеріалів для виготовлення одягу та інших виробів за різними критеріями. До запропонованих угруповань належать асортимент використовуваних матеріалів та декоративних елементів; сезонність, призначення та стильові ознаки; характер малюнка поверхні матеріалу та забарвлення; спосіб виробництва та сировинний склад, обробка поверхні матеріалу та з'єднання елементів; оптичні властивості, сила візуального впливу та стан тактильних відчуттів; кількість шарів та ступінь рельєфності; кольорові поєднання, комбінаторні принципи та чуттєво-емоційне сприйняття тощо (рис. 1).

Важливим показником естетичної якості виробу є характер рисунка поверхні матеріалу. За геометричними ознаками вирізняють опуклі, увігнуті, рівні, ламані, хвилясті, ребристі тощо поверхні [3]. Наприклад, хвилясті поверхні утворюють рюши та волани, ламані - складки, гофре, плісе, а ребристі - деякі різновиди буфів та перфорації. Крім того, малюнок поверхні матеріалу обумовлений його сировинним складом, способом виробництва та оздобленням [4].

Дизайн-проектування одягу та інших виробів передбачає використання матеріалів як 3 природними (натуральними), так i похідними, тобто штучно створеними фактурами. Деякі натуральні матеріали, такі як, наприклад, хутро та шкіра екзотичних тварин, використовують для виготовлення одягу, аксесуарів тощо, зберігаючи природний малюнок поверхні.

Зазвичай їх застосовують для категорії виробів класу «люкс», які є ідентифікаторами певного стилю життя, суспільного статусу, рівня соціальної відповідальності тощо споживачів. 


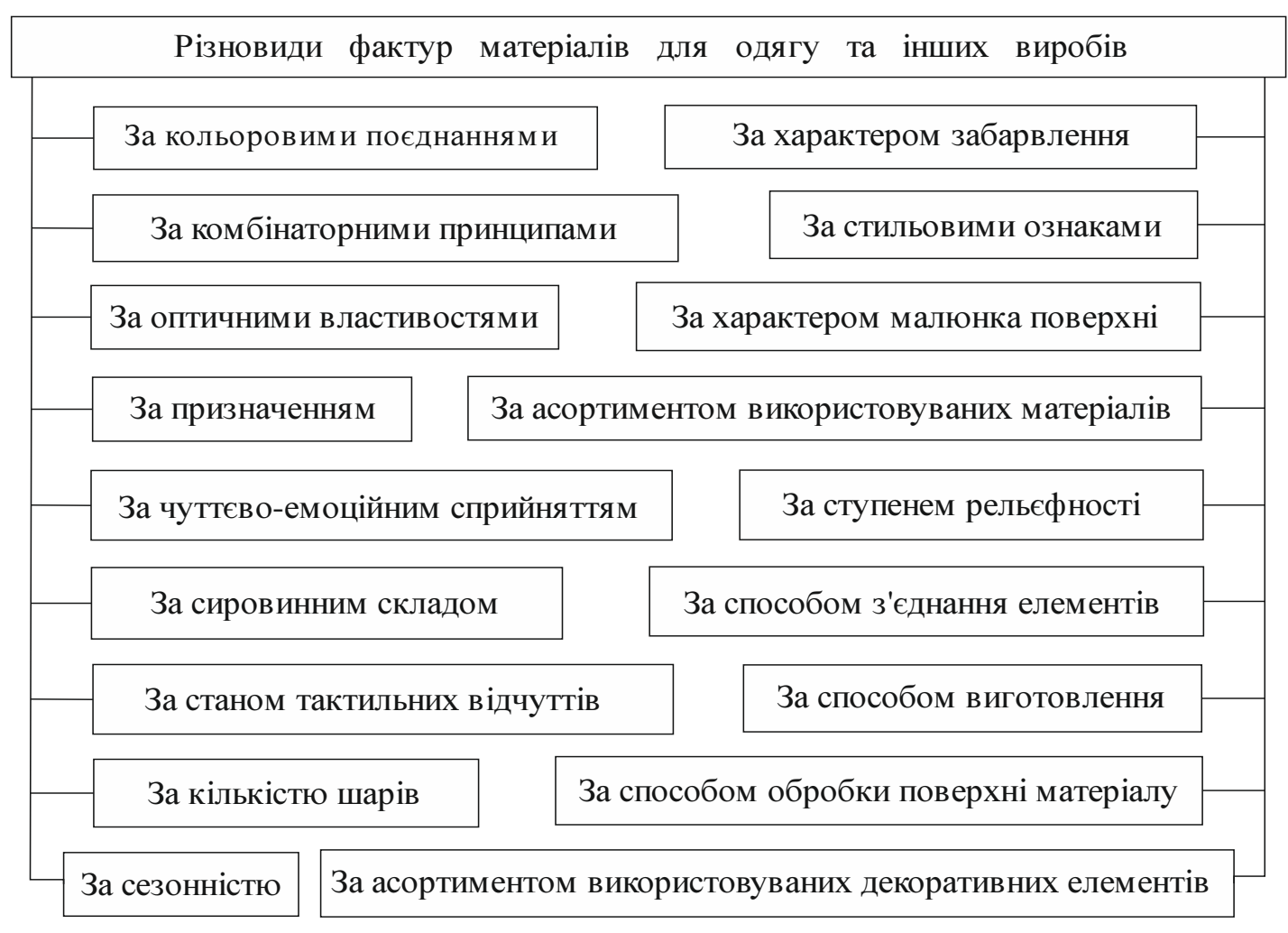

Рис. 1. Класифікація різновидів фактур матеріалів для одягу та інших виробів

Штучні фактури отримують шляхом технологічної обробки поверхні, у процесі якої відбувається зміна первинного матеріалу та надання йому нових візуально-пластичних якостей. Наприклад, застосування різноманітних способів обробки натуральної шкіри та хутра 3 метою покращення естетичних, ергономічних, функціональних тощо характеристик виробів 3 них.

Розповсюдженою та актуальною тенденцією у наш час $\epsilon$ також імітація природних фактур. Відомі сучасні світові бренди одягу, орієнтовані на екопроблематику, відмовляються від використання шкіри та хутра тварин на користь їх високоякісних штучних замінників, виготовлених 3 новітніх матеріалів 3 застосуванням креативних технологій, не зважаючи на їх дорожнечу у виробництві. Формується нове покоління одягу, аксесуарів та інших виробів, що потребує осучаснення підходів до його дизайнпроектування.

Розрізняють ручний, механізований (автоматичний) i комбінований способи виготовлення фактури (рис. 2).

До першого способу належать вишивка нитками, бісером, паєтками, стрічками; буфи; аплікація; інкрустація; розпис (вільний розпис, гарячий та холодний батік); в'язання; плетіння; валяння (сухе, мокре, на текстильному матеріалі); орігамі; об'ємні елементи 3 наповненням; печворк; квілтінг; випалювання, витравлювання тощо (рис. 3).

Характерною особливістю ручного способу виробництва $\epsilon$ висока трудоємність, тому його використовують переважно для створення ексклюзивних виробів, які вирізняються оригінальністю, художньою виразністю, високою якістю та вартістю, або навіть можуть бути витворами мистецтва. Крім того, ручне виробництво фактур застосовують для реконструкції історичних костюмів та інших виробів. За відсутності обгрунтованої потреби використання ручної праці, виготовлення фактури може відбуватися автомати-зованим способом. 


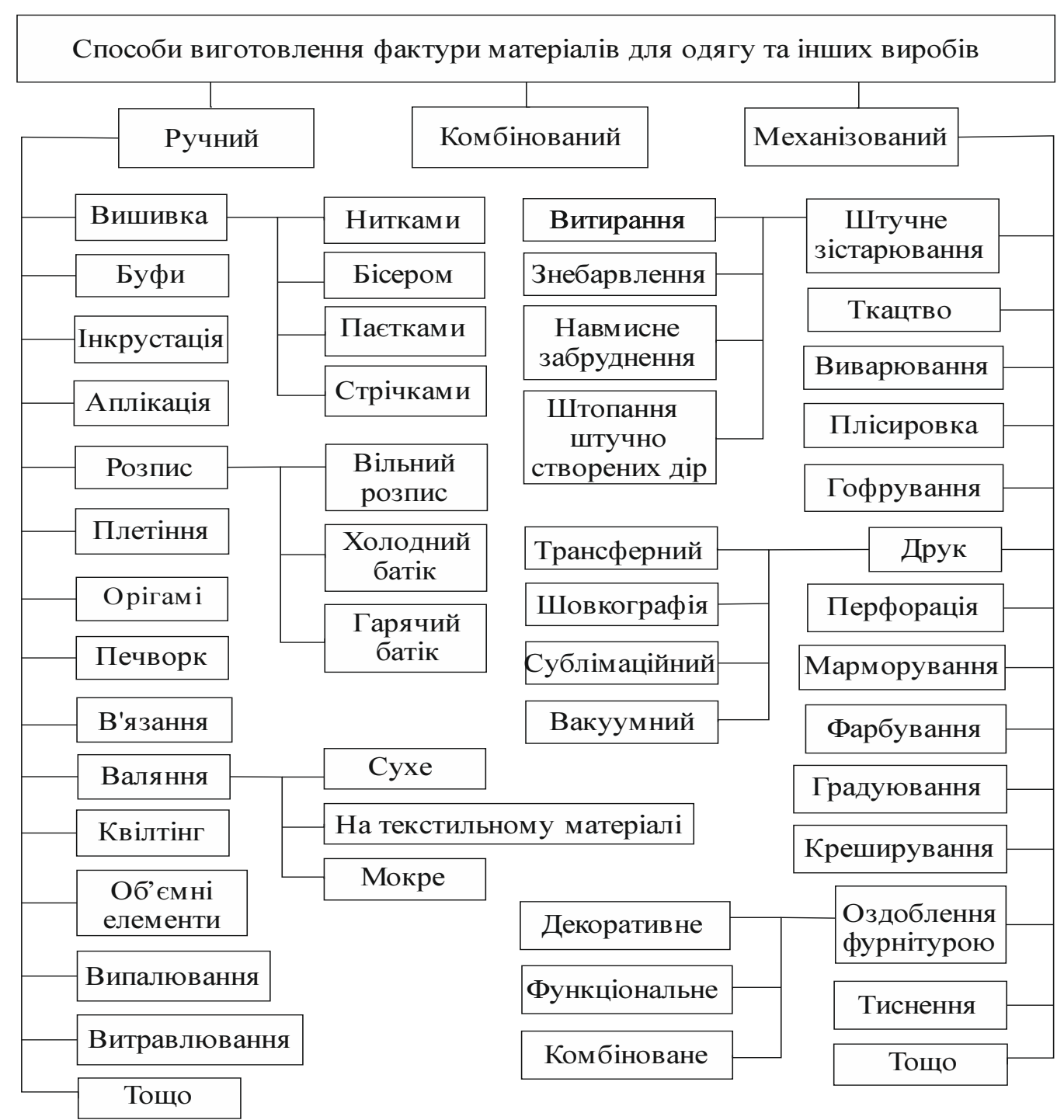

Рис. 2. Систематизація способів виробництва фактури матеріалів для одягу та інших виробів

Завдяки використанню сучасного обладнання урізноманітнюються техніки створення фактур механізованим (автоматизованим) способом, що також дозволяе значно скоротити час виконання роботи [7]. Серед фактурних ефектів, виготовлених на швейному та іншому обладнанні, найбільш розповсюдженими $\epsilon$ ткацькі переплетення, штучне зістарювання

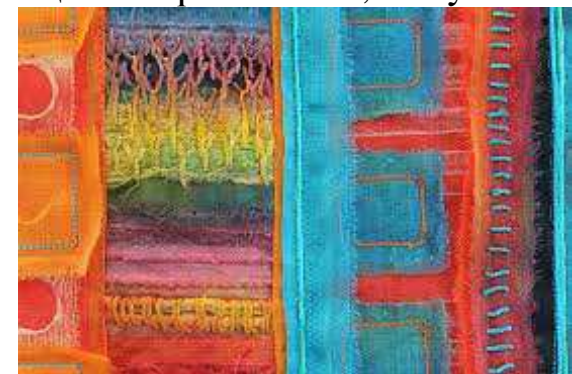

a

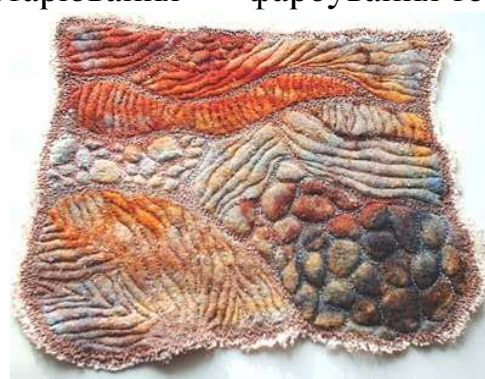

б (витирання, знебарвлення, навмисне забруднення, штопання штучно створених дір), плісировка, гофрування, креширування, марморування, тиснення, друк (трансферний, шовкографія, сублімаційний, вакуумний), градуювання, витравлювання, перфорація, оздоблення фурнітурою (декоративне, функціональне, комбіноване), градуювання, фарбування тощо [8] (рис. 4). 


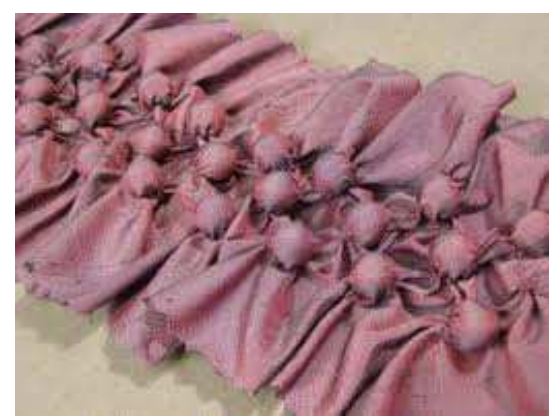

$\boldsymbol{\Gamma}$

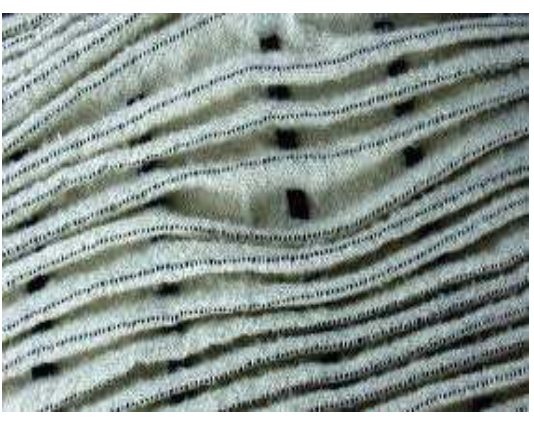

Д

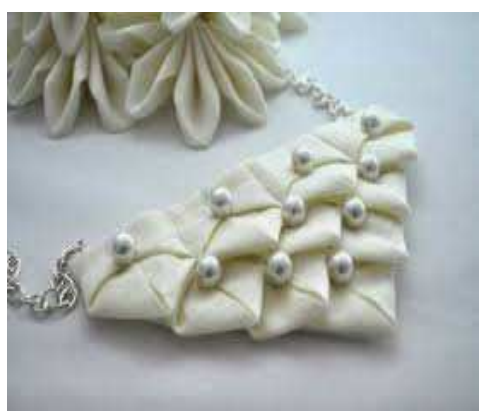

e

Рис. 3. Приклади фактур ручного способу виготовлення:

a - аплікація; б - мокре валяння; в - випалювання; г - використання об'ємних елементів; д - буфи; е - техніка орігамі [5,6]

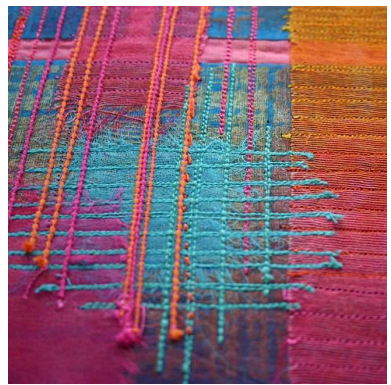

a

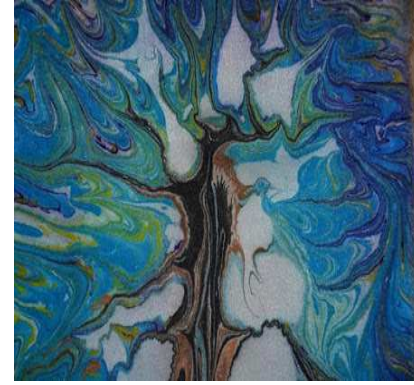

б

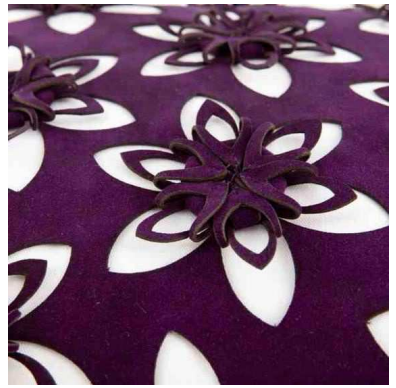

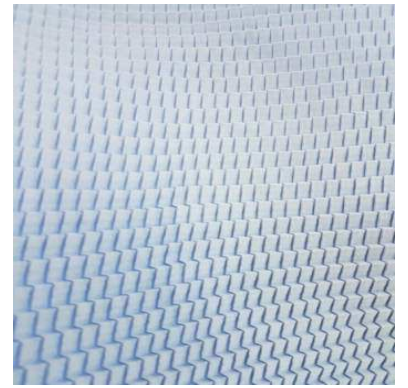

Рис. 4. Приклади фактур машинного способу виготовлення: а - ткацтво; б - марморування; в - перфорація ; г - гофрування [9]

Поширеним $\epsilon$ автоматизоване виготовлення фактурних ефектів для одягу, аксесуарів, іграшок та інших виробів. Але деякі способи створення фактур мають обмежений діапазон застосування. Наприклад, штучне зістарювання найчастіше використовують для виготовлення виробів декоративного призначення. Така техніка не застосовується для повсякденного одягу за виключенням джинсового, оскільки в процесі витирання, знебарвлення та штопання навмисно створених дір матеріал втрачає міцність (рис. 5, рис. 6).

Окремим різновидом оздоблення $\epsilon$ японська техніка штопання «боро» 3 використанням великої кількості дрібних елементів, як правило, різного матеріалу, що нашаровуються один на одного та з'єднуються різнокольоровими нитками. Такий спосіб дозволяє створювати оригінальні та естетично привабливі фактури.

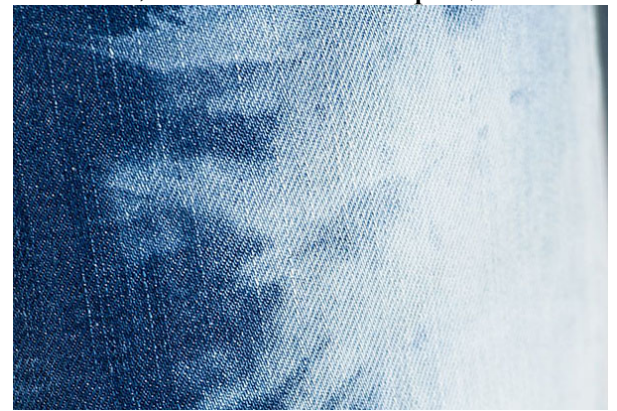

a

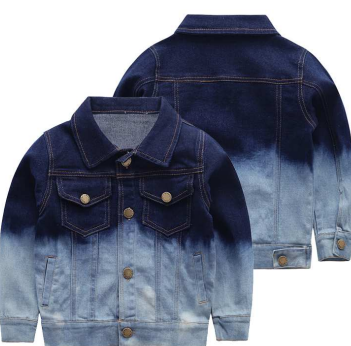

б

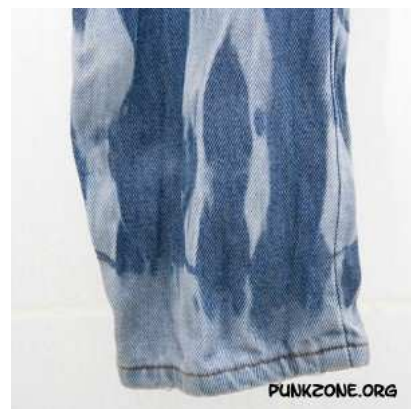

Рис. 5. Приклади застосування техніки знебарвлення джинсового одягу: a - хаотичними плямами; б - градієнтне; в - вертикальними смужками [7] 


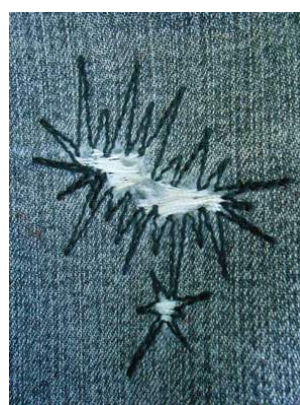

a

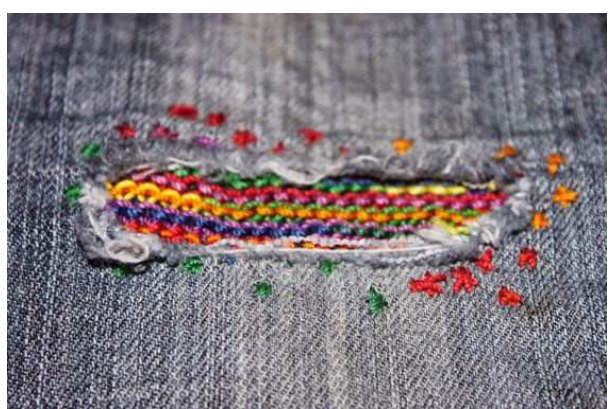

б

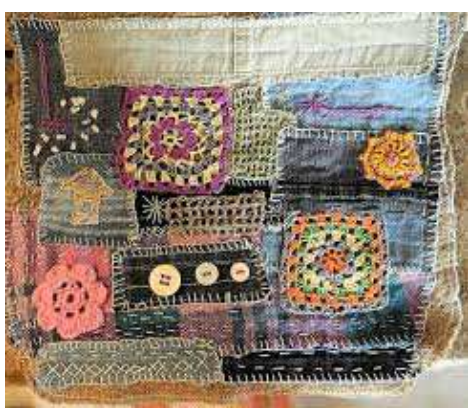

B

Рис. 6. Приклади застосування техніки штопання штучно створених дір:

a - нитками того ж кольору, що і тканина; б - контрастними нитками; в - 3 використанням накладних елементів [10]

Перфорація 3 дрібними отворами прикрашає та сприяє підвищенню повітропроникності повсякденного літнього одягу, взуття, аксесуарів, виробів з текстилю тощо. Крупна перфорація $\in$ незручною та непрактичною у використанні, тому здебільшого іiі застосовують за потреби як активний декоративний елемент, що привертає увагу. Сучасні методи друку дозволяють створювати чіткі, яскраві та зносостійкі зображення на матеріалах для одягу та інших виробів. У такий спосіб оздоблюють вироби як широкого вжитку, що випускаються у великій кількості, так і виключно індивідуальні, наприклад, іменна подушка чи одяг із зображенням власника. Принт може грати інформативну, декоративну i навіть стилеутворюючу роль залежно від змісту зображення. Найбільш розповсюдженими $\epsilon$ друковані оздоблення у вигляді тексту, рисунка або комбіновані.

Для створення складних багатошарових фактур часто використовують комбіновані техніки. Наприклад, поєднання вишивки та перфорації, валяння та оздоблення фурнітурою, розпису та випалювання тощо.

Вибір техніки виготовлення фактури значною мірою залежить від сировинного складу матеріалів використовуваних для створення задуманого виробу. Так, наприклад, випалюванню краще піддаються натуральна шкіра та штучні матеріали (тафта, органза), які не горять, а плавляться і під дією термовпливу утворюють оригінальну рельєфну поверхню. Знебарвлення, фарбування та градуювання діє єфективніше у роботі 3 натуральними та матеріалами змішаного сировинного складу. Зазвичай виготовлення нової фактури $\epsilon$ частиною експериментальних досліджень i передбачає аналіз властивостей як вже відомих, так і нових матеріалів.

Великий вплив на формування зорового образу в одязі та інших виробах мають оптичні властивості поверхні матеріалу [11], а саме здатність матеріалу кількісно та якісно впливати на світловий потік і виявляти колір, блиск та прозорість. Відомо [12], що колір - це зорове відчуття світла певного хвильового складу, основними характеристиками якого в матеріалі є кольоровий тон, насиченість та світлота. Кольоровий тон відповідає певній ділянці спектрального кола. Насиченість як якісна характеристика відчуття кольору дозволяє розпізнавати два кольори одного тону, але різної інтенсивності. Світлота кількісна характеристика відчуття кольору i показує ступінь спільного між даним кольором та білим. Блиск $\epsilon$ результатом специфічного сприйняття людиною відбитого світлового потоку i залежить від ступеня гладкості поверхні, структури матеріалу та характеру оздоблення. Фактури матеріалів можуть бути матові - коли світло від нерівної, шорсткої поверхні відбивається у різних напрямах; глянцеві - якщо світло від поверхні відбивається в тому напрямі, що й падає; мерехтливі - при відбитті світла від поверхні в певному напрямі; при повному відбитті світла виникають дзеркальні фактури - за умови, що поверхня матеріалу $\epsilon$ близька до ідеально гладенької [13]. Ступінь прозорості залежить від здатності матеріалу пропускати промені світла. Чим більше світла відбиває чи поглинає поверхня тим менш вона прозора. Для виробництва одягу та інших виробів використовують прозорі, напівпрозорі та непрозорі матеріали. Відомо, що в сучасній проектній практиці дизайну колір є важливим 
фактором

психофізіологічного комфорту (сприйняття кольору) та емоційно-естетичного впливу (почуття кольору), а також носієм візуальної інформації. Тому колір визначають ще в процесі розробки ескізу виробу. $3 a$ кольоровими поєднаннями фактури можуть бути хроматичні, ахроматичні, теплі, холодні, контрастні, споріднені, тотожні або комбіновані залежно від складу кольорів.

За характером поверхні матеріалу розрізняють гладенькі, шорсткі, рельєфні, повстеподібні, ворсові, комбіновані тощо фактури. Гладенька поверхня є рівною з чітким малюнком переплетення. Шорстку фактуру вирізняють нерівні, вузликові, зернисті поверхні, які в свою чергу розділяються на дрібно- та грубозернисті поверхні. Такий ефект, як правило, можна отримати завдяки використанню спеціальних ткацьких переплетень або в'язання; плетіння; вишивки грубими нитками, бісером, стрічками; оздоблення фурнітурою тощо. Рельєфна фактура досягається виготовленням переплетень, що утворюють рельєфний візерунок в результаті використання ниток або інших матеріалів різної товщини та оздоблювальних операцій, які сприяють утворенню об'ємного малюнка (креш, тиснення, гофре). Для створення рельєфної поверхні застосовують плісировку, гофрування, тиснення, перфорацію, буфи, об'ємні елементи з наповненням тощо. Ступінь рельєфності фактури може бути незначною, помірною або екстремальною. Ефект повстеподібної або валяної поверхні досягається в результаті механічної обробки (валяння) 3 метою іiі ущільнення таким чином, що повстеподібний застил повністю закриває малюнок переплетення. Різновидами ручного способу виробництва є сухе валяння, мокре та валяння на текстильному матеріалі. Ворсова фактура може бути створена в результаті начісування, використання ворсового i петельного переплетень, а також шляхом приклеювання ворсу, який, як правило, знаходитися на лицьовій стороні.

Кожна фактура несе в собі ознаки певного емоиійно-образного сприйняття. Матеріали мають різну за своєю виразністю поверхню в залежності від величини і кількості елементів фактури на одиницю площі, наприклад, крупний малюнок фактури візуально зменшує розміри поверхні, а дрібний, навпаки - збільшує. Використовуючи розміщення деталей 3 крупним малюнком у «композиційній рамці» 3 елементів, що мають легку фактуру, можна візуально зменшити розміри об'єкта, а його пропорції -

скорегувати. Розрізняють пасивні фактури 3 однорідною нейтральною поверхнею i дуже дрібними елементами та активні - зі складною рельєфною поверхнею і крупними елементами. Активні фактури декоративно насичені і не потребують додаткового оздоблення. Пасивні фактури слугують фоном для активних або їх доповненням. Кожна фактура по-різному взаємодіє з формою виробу. Так, наприклад, гладенькі та блискучі поверхні візуально зменшують об'єм, створюють м'які форми. Матеріали 3 яскраво вираженою рельєфністю, як, наприклад, широкий рубчик і букльовані, навпаки, візуально збільшують об'єм та важкість форми. Тканини 3 довгим ворсом додають формі виробу округлості та узагальненості. Завиткові натуральні та штучні хутра мають здатність додавати формі монолітність, цілісність, скульптурну чіткість, оскільки з'єднання окремих частин форми завдяки посиленій фактурності матеріалу візуально не відчутні.

Тактильні властивості визначаються сприйняттям матеріалів на дотик, які за характером туше розділяють на приємні, неприємні, теплі, холодні тощо [14]. Крім того, за станом тактильних відчуттів матеріали можуть бути сухі, пружні, рихлі, маслянисті, м'які тощо. До сухих - хрустких, папероподібних, належать органза, тафта, льон, шовк, поплін. Такі матеріали дозволяють створювати стійкі форми з чіткими контурами, хоча мають певні технологічні труднощі в процесі виготовлення виробів. Як правило, вони забарвлені в спокійні, пастельні тони. Ці особливості використовують для створення стриманих, чітких геометричних форм одягу та текстильних виробів повсякденного призначення, а також спеціального одягу. Пружні матеріали (наприклад, поліамід) створюють об'ємні легкі форми зі складками, що мають підвищену жорсткість та формостійкість. При використанні прозорих тканин, такі форми виконуються 3 мінімальною кількістю швів, оскільки вони ускладнюють сприйняття виробу. Рихлі матеріали - об'ємні, пористі, пухнасті (наприклад, махрові та 
букльовані) створюють м'яку, нестійку форму. Маслянисті (наприклад, креп-сатин) мають високу відбивну здатність (завдяки сатиновому переплетенню) і драпірувальність. 3 подібних тканин можна створювати рухливі форми, які підкреслено грою відблисків. Пластичні i спадаючі матеріали $є$ м'якими, крім того, вони добре драпіруються та створюють невиразні, нестійкі, рухливі форми.

Для посилення художньої виразності фактури тканини можна виділити способи, засновані на використанні зміни ниток різного сировинного складу і товщини та численних варіантах переплетень, а також видів опорядження (механічного, хімічного). Вагоме значення при зоровому сприйнятті малюнка на поверхні матеріалу має відповідність фактури ii колористичному оформленню. Забарвлення фактур для одягу та інших виробів може носити однотонний, різнокольоровий, градієнтний та візерунчатий характер. Градуювання передбачає поступовий перехід від одного кольору до іншого, не обов'язково спорідненого, і застосовується для забарвлення фактур 3 шовку, шифону, трикотажу, шкіри, хутра тощо. Одним з варіантів такої техніки $\epsilon$ «деграде» (від французького degrade) деградування кольору, тобто перехід від темного до світлішого, який можна досягнути шляхом фарбування або використання накладних елементів, стрічок, намистин, паєток, бісеру тощо.

Серед візерунчастих фактур $€$ орнаментовані, абстрактні, сюжетні, тематичні тощо. Орнаментальні мотиви можуть бути геометричними, рослинними, зооморфними та антропоморфними. За характером композиції розповсюдженими $є$ стрічкові, центричні, крайові, геральдичні, рівномірно заповнені або комбіновані орнаменти. Це зазвичай обумовлено формою та конструктивними особливостями виробу. Різноманітні кольорові плями та невизначені контури є абстрактним або безпредметним малюнком. На гобеленах, деяких тканинах, платках, скатертинах часто розміщують сюжетні зображення 3 певним зміст (портрети, пейзажі, натюрморти тощо). Найбільш поширеними є тематичні малюнки - вони мають конкретне визначення, наприклад, горох, смужка, клітинка, ромб, меандр тощо.

Поверхня форми також впливає на зовнішній вигляд виробу i визначає його зоровий образ. Використання в одній моделі матеріалів різних фактур дає можливість підкреслити особливості кожного виробу. Комбінаторні принципи поєднання матеріалів можуть виражатись через контраст, спорідненість або тотожність, коли композиція побудована на витончених переходах однієї фактури в іншу. Наприклад, поєднання ідентичних за кольором, але принципово різних за тактильними, оптичними, рельєфними, сезонними тощо властивостями матеріалів $\epsilon$ контрастом фактур. А використання контрастного або спорідненого забарвлення допомагає знаходити цікаві рішення при комбінуванні однотипних за текстурою матеріалів.

Висновки. Доведено, що фактура $\epsilon$ безпосереднім активним естетичним та емоційним засобом впливу на формування образу костюму i важливою складовою проектних методів. Розкрито можливості структури поверхні матеріалу, як ефективного засобу посилення художньої виразності образу, а також прогнозування та корегування сприйняття пропорцій та форми одягу в цілому. Узагальнено i систематизовано асортимент існуючих різновидів фактур матеріалів за різними класифікаційними угрупуваннями та виокремлено такі, що $\epsilon$ найбільш використовуваними у дизайнпроектуванні одягу та інших виробах. Визначено та обгрунтовано сфери можливого застосування, а також надано рекомендації щодо оптимального вибору техніки виготовлення фактури при розробці нових моделей одягу та інших виробів 3 метою ефективного використання іï специфічних властивостей. Акцентовано увагу на праві фактури бути об'єктом дизайну. Сформований матеріал спрямовано на створення інформаційної бази для удосконалення дизайн-проектування 3 перспективою подальшого іiі розширення.

\section{Література}

1. Колосніченко М.В. Ергономіка і дизайн. Проектування сучасних видів одягу: навч. посібн. / М.В. Колосніченко, Л.І. Зубкова, К.Л. Пашкевич, Т.О. Полька, Н.В. Остапенко, І.В. Васильєва, О.В. Колосніченко. - Київ: ПП «НВЦ «Профі», 2014. $386 \mathrm{c}$.

2. Малинська А.М. Розробка колекцій одягу: навч. посібн. / А.М. Малинська, К.Л. Пашкевич, М.Р. Смирнова, О.В. Колосніченко. - Київ: ПП НВЦ 
«Профі», 2014. - 140 c.

3. Ніколаєва Т.В. Тектоніка формоутворення костюма: Навчальний посібник. - К. : Арістей, 2011. - $340 \mathrm{c}$.

4. Пашкевич К.Л. Теоретичні основи дизайну одягу на засадах тектонічного підходу: автореф. дис. ... д-ра техн. наук: спец. 05.01.03 «Технічна естетика» / К.Л. Пашкевич. - Київ, 2017. - 45 с.

5. Сайт журналу «Threades» [Електронний ресурс]. http://www.threadsmagazine.com.

6. Сайт «Aventures textiles» [Електронний ресурс]. https://aventurestextiles.blogspot.ru.

7. Kolosnichenko O.V. The development of new forms of special clothes by design projectsing methods / O.V. Kolosnichenko, N.V. Ostapenko, M.V. Kolosnichenko // Vlakna a Textile. - 2016. - № 2. - P. $\underline{3-8 .}$

8. Pashkevich K.L. Research of some physical and mechanical characteristics of suiting fabrics for designing the clothes / K.L. Pashkevich, M.V. Kolosnichenko, N.V. Ostapenko // Vlakna a Textile. 2016. - № 1. - P. 3 - 8 .

9. Сайт «Coroflot» [Електронний ресурс]. Режим доступу: http://www.coroflot.com /astamasiulyte/Texture.

10. Сайт «Ruth Singer textile artist» [Електронний ресурс]. - Режим доступу: https://ruthsinger.com.

11. Kolosnichenko O.V. Design of new articles of clothing using principles of contemporary style directions in Architecture and art / O.V. Kolosnichenko, I.O. Pryhodko-Kononenko, N.V. Ostapenko // Vlakna a Textile. - 2016. - № 1. - P. $18-23$.

12. Аренхейм Р. Искусство и визуальное восприятие. - М. : Издательство «Прогресс», 1974. $391 \mathrm{c}$. $224 \mathrm{c}$.

13. Едвардс Б. Цвет. - М. : Попурри, 2014. -

14. 14. Супрун Н.П. Конфекціонування матеріалів для одягу : навч. посібн. / Н.П. Супрун, Л.В. Орленко, Е.П. Дрегуляс, Т.О. Волинець. - Київ: Знання, 2008. - 246 с.

\section{References}

1. Kolosnichenko, M.V., Zubkova, L.I., Pashkevych, K.L., Pol'ka, N.V. Ostapenko, Vasyl'yeva, I.V., et al. (2014). Erhonomika i dyzayn. Proektuvannya suchasnykh vydiv odyahu: Navchal'nyy posibnyk [Ergonomics and design. Designing modern types of

\section{ОБОБЩЕННАЯ СИСТЕМАТИЗАЦИЯ}

РАЗНОВИДНОСТЕЙ ФАКТУР МАТЕРИАЛОВ ДЛЯ ДИЗАЙН-ПРОЕКТИРОВАНИЯ ОДЕЖДЫ МИХАЙЛЮК О.Ю., КОЛОСНИЧЕНКО М.В., ОСТАПЕНКО Н.В., ГАЕВАЯ И.Л., АНТОНЮЖЕНКО А.Ю.

Киевский национальный университет технологий $u$ дизайна clothin]. Kyiv: PP NVTs Profi [in Ukrainian].

2. Malyns'ka, A.M., Pashkevych, K.L., Smyrnova, M.R. \& Kolosnichenko, O.V. (2014). Rozrobka kolektsiy odyahu [Clothing collection development]. Kyiv: PP NVTs Profi [in Ukrainian].

3. Nikolayeva, T. (2011). Tektonika formoutvorennya kostyuma [Tectonics of shaping suit]. Kyiv [in Ukrainian].

4. Pashkevych, K.L. (2017). Teoretychni osnovy dyzaynu odyahu na zasadakh tektonichnoho pidkhodu [Theoretical foundations of clothes design on the basis of a tectonic approach]. Extended abstract of Doctore's thesis. Kyiv [in Ukrainian].

5. Sait zhurnalu «Threades» [Site of journal «Threades»]. www.threadsmagazine.com. Retrieved from http://www.threadsmagazine.com [in English].

6. Sait «Aventures textiles» [Site «Aventures textiles»]. aventurestextiles.blogspot.ru. Retrieved from https://aventurestextiles.blogspot.ru [in Russian].

7. 7. Kolosnichenko, O.V., Ostapenko, N.V.\& Kolosnichenko, M.V. (2016). The development of new forms of special clothes by design projectsing methods. Vlákna a textil - Fibers and textiles, 2, 3-8 [in English].

8. Pashkevich, K.L., Kolosnichenko, M.V. \& Ostapenko, N.V. (2016). Research of some physical and mechanical characteristics of suiting fabrics for designing the clothes. Vlákna a textil - Fibers and textiles, 1, 3-8 [in English].

9. Sait «Coroflot» [Site «Coroflot»]. www.coroflot.com/astamasiulyte/Texture. Retrieved from http://www.coroflot.com/astamasiulyte/Texture [in English].

10. Sait «Singer textile artist» [Site «Ruth Singer textile artist»]. ruthsinger.com. Retrieved from https://ruthsinger.com [in English].

11. Kolosnichenko, O.V., Pryhodko-Kononenko, I.O. \& Ostapenko, N.V. (2016). Design of new articles of clothing using principles of contemporary style directions in Architecture and art. Vlákna a textil Fibers and textiles, 1, 18 - 23 [in English].

12. Arenkheym, R. (1974). Yskusstvo y vyzual'noe vospryyatye. [Art and visual perception]. Moscow [in Russian].

13. Edvards, B. (2014). Tsvet [Color]. Mynsk [in Russian].

14. Suprun, N.P., Orlenko, L.V., Drehulyas, E.P. \& Volynets, T.O. (2008). Konfektsionuvannya materialiv dlya odyahu [Confectionery materials for clothing]. Kyiv: Znannya [in Ukrainian].

GENERALIZED SYSTEM RATINGS OF SURFACE OF THE MATERIALS FOR DESIGN OF CLOTHES

MIKHAILUK O., KOLOSNICHENKO M., OSTAPENKO N., HAIOVA I., ANTONUJENKO A.

Kiev National University of Technologies and Design 
Цель. Целью данного исследования является разработка обобщенной классификации разновидностей фактур материалов для изготовления одежды и других изделий.

Методология. В проведении исследований использован комплекс общенаучных подходов: визуально-аналитический, системно-информационный и метод классификаций.

Результаты. На основе проведенных исследований проанализированы и обобщены существующие разновидности фактур материалов для изготовления одежды и других изделий. Выделены и раскрыты особенности формирования и прогнозирования восприятия тектонически совершенного одежды.

Научная новизна. На основе теоретических исследований классифицированы существующие разновидности фактур материалов для изготовления одежды и других изделий по различным критериям, систематизированы способы их производства. Доказана возможность прогнозирования восприятия гармоничного художественно-выразительного образа благодаря применению фактурных эффектов.

Практическая значимость. Сформирована информационная база разновидностей фактур материалов для дизайн-проектирования одежды и других изделий.

Ключевье слова: дизайн-проектирование, фактура, классификация, одежда.
Purpose. The purpose of this study is to develop a generalized classification of types of invoices of materials for the manufacture of clothing and other products.

Methodology. In the research the complex of general scientific approaches was used: visual-analytical, system-informational and the method of classifications.

Findings. On the basis of the conducted researches, existing types of invoices of materials for making clothes and other products are analyzed and summarized. The peculiarities of forming and predicting the perception of tectonically perfect clothes are singled out and disclosed.

Originaliti. On the basis of theoretical studies, existing types of invoices of materials for the manufacture of clothes and other products according to different criterias are classified, the methods of their production are systematized. The possibility of predicting the perception of a harmonious artistic and expressive image through the application of textural effects has been proved..

Practical value. The information base of the types of materials invoices for designing of clothing and other products has been formed.

Key words: design-engineering, texture, classification, clothing. 